\section{DETERMINATION OF MECHANICAL PROPERTIES OF COMPOSITE SANDWICH PANEL WITH ALUMINIUM HONEYCOMB CORE} MICHAL SKOVAJSA FRANTISEK SEDLACEK

MARTIN MRAZEK

University of West Bohemia

Faculty of Mechanical Engineering

Plzen, Czech Republic

DOI: 10.17973/MMSJ.2021_12_2021132

e-mail: SKOVI@KKS.ZCU.CZ

This paper deal with comparison of mechanical properties of composite sandwich panel with aluminium honeycomb core which is determined by experimental measurement, analytic calculation and numerical simulation. The goal was to compared four composite sandwich panels. The composite sandwich panels were made of two different aluminium honeycomb cores with density 32 and $72 \mathrm{~kg} \cdot \mathrm{m}^{-3}$ and two different layup of skin with 4 and 5 layers. The comparison was performed on a threepoint bend test with support span $400 \mathrm{~mm}$. This paper confirms the possibility of a very precise design of a composite sandwich panel with an aluminium honeycomb core using analytical calculation and numerical simulation.

KEYWORDS

Numerical analysis, Carbon fibre, Composite, Sandwich Experimental measurement.

\section{INTRODUCTION}

Research into the theoretical analysis of sandwich constructions began following World War Two with several papers being published between 1945 and 1955 on the strength and stability of sandwich beams, columns and plates. A structural sandwich is a special form of a laminated composite comprising of a combination of different materials that are bonded to each other so as to utilise the properties of each separate component to the structural advantage of the whole assembly. [Zenkert 1995] Sandwich panel cured structures provide an opportunity to reduce the weight and assembly costs of structures that would otherwise use mechanical fasteners. The term sandwich structure normally means a structure that is adhesively bonded with skins on the outside and some type of lightweight core material on the inside. Fig. 1

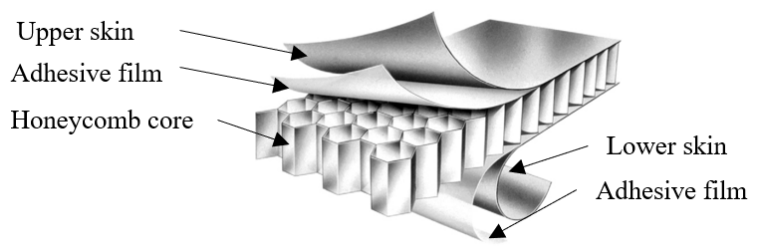

Figure 1. Composite honeycomb sandwich panel [Bitzer 1997]

Sandwich structure can be fabricated by first curing the separate composite details and then adhesively bonding them to form a completed assembly. Alternatively, in curing, the skins are cured at the same time that they are bonded to the interior sandwich.
A third option is a cured, unitized structure in which all of the details are cured together at the same time without an interior sandwich to produce a one-piece structure. [Campbell 2010] This paper deal with comparison of mechanical properties of composite sandwich panel with aluminium honeycomb core which is determined by experimental measurement, analytic calculation and numerical simulation. The result of this comparison is the determination of the deviation between the given calculation methods and experimental measurements. Knowledge of this deviation and the calculation procedure can help in designing the composite honeycomb sandwich panel.

\section{ASSESSED SPECIMEN}

The mechanical properties assessment was performed by 3 point bending test on a composite sandwich panel. The size of the test specimen was $100 \times 500 \mathrm{~mm}(\mathrm{bxL})$ according to Fig. 2 . The specimen thickness is specific to each sample type and it is given in the Tab. 4.

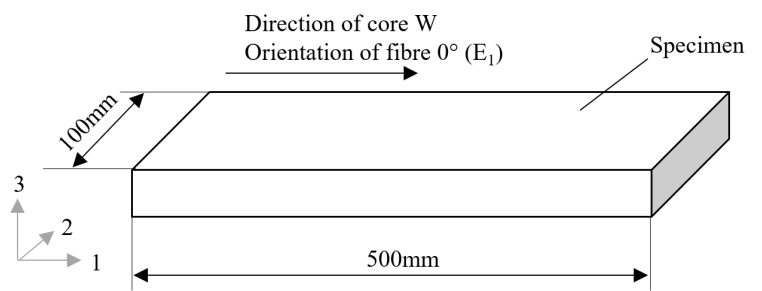

Figure 2. Assessed test specimen

The setting of the test specimen for experimental measurements, numerical simulation and analytical calculation was performed according to the diagram on Fig. 3 with a support distance of $400 \mathrm{~mm}$.

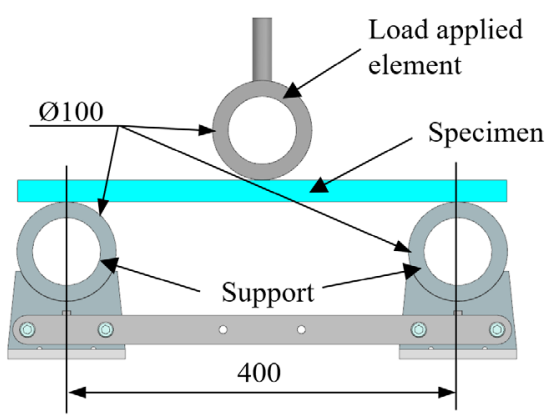

Figure 3. Scheme of specimen placement during the 3-point bend test

Four different test specimens listed in Tab. 1 with two different cores and two different coating thicknesses were evaluated.

\begin{tabular}{|c|c|c|c|}
\hline $\begin{array}{c}\text { Specimen } \\
\text { identification }\end{array}$ & $\begin{array}{c}\text { No. of } \\
\text { layer }\end{array}$ & Material of core & $\begin{array}{c}\text { Thickness } \\
\text { of core } \\
(\mathrm{mm})\end{array}$ \\
\hline P[4]_C[3,2/72] & & $\begin{array}{c}\text { PAMG-XR1-4.5-1/8- } \\
10-P-5056\end{array}$ & \\
\hline P[4]_C[4,8/32] & 4 & $\begin{array}{c}\text { PAMG-XR1-2.0-3/16- } \\
\text { 07-P-5056 }\end{array}$ & 20 \\
\hline P[5]_C[3,2/72] & & PAMG-XR1-4.5-1/8- \\
10-P-5056 & \\
\hline P[5]_C[4,8/32] & 5 & PAMG-XR1-2.0-3/16- \\
\hline
\end{tabular}

Table 1. List of samples to be assessed

The composite honeycomb sandwich panel which we assessed was made of carbon fabric twill CC200 with Toray T300 3K fibre with a weight of $200 \mathrm{~g} . \mathrm{m}^{-2}$ produced by KordCarbon Company with epoxy resin EE 130-90 C2 and two aluminium honeycomb core PAMG-XR1-4.5-1/8-10-P-5056 with density $72 \mathrm{~kg} \cdot \mathrm{m}^{-3}$ and PAMG-XR1-4.5-1/8-10-P-5056 with density $32 \mathrm{~kg} \cdot \mathrm{m}^{-3}$ produced 
by Plascore company. The composite orthotropic materials such as carbon fabric laminates are characterized by 9 material constants to determine the mechanical properties in all three directions. [Campbell 2010] We used the material properties for our material given by (Table 2 ) in the FEM model and analytical calculation, which were previously determined by experimental measurement.

\begin{tabular}{|c|c|c|}
\hline \multicolumn{2}{|c|}{ Material properties } & Value \\
\hline \multirow{2}{*}{ Young's modulus } & $E_{1}$ & $52.3(\mathrm{GPa})$ \\
\hline & $E_{2}$ & $48.7(\mathrm{GPa})$ \\
\hline \multirow{3}{*}{ Shear modulus } & $E_{3}$ & $5(\mathrm{GPa})$ \\
& $\mathrm{G}_{12}$ & $2.32(\mathrm{GPa})$ \\
\hline \multirow{2}{*}{ Poisson's ratio } & $\mathrm{G}_{13}$ & $2(\mathrm{GPa})$ \\
\hline & $\mathrm{G}_{23}$ & $2(\mathrm{GPa})$ \\
\hline & $\mu_{12}$ & $0.11(-)$ \\
\hline & $\mu_{13}$ & $0.35(-)$ \\
\hline
\end{tabular}

Table 2. Material properties of Twill CC200 - Toray T300 3K [Skovajsa 2021]

The material properties of honeycomb cores were given by material datasheet from the manufacturer and were listed in the table 3

\begin{tabular}{|c|c|c|}
\hline Properties & $\begin{array}{c}\text { PAMG- } \\
\text { XR1-4.5- } \\
1 / 8-10-P- \\
5056\end{array}$ & $\begin{array}{c}\text { PAMG- } \\
\text { XR1-2.0- } \\
3 / 16-07-P-\end{array}$ \\
\hline Cell size $(\mathrm{mm})$ & 3.2 & 4.8 \\
\hline Density (kg.m $\left.{ }^{-3}\right)$ & 72 & 32 \\
\hline Compressive strength (MPa) & 4.76 & 1.37 \\
\hline $\begin{array}{c}\text { Young's modulus } \\
\text { in compression (GPa) }\end{array}$ & 1.27 & 0.31 \\
\hline $\begin{array}{c}\text { Shear strength in the L } \\
\text { direction (MPa) }\end{array}$ & 2.97 & 1.06 \\
\hline $\begin{array}{c}\text { Shear modulus } \\
\text { in the L direction (GPa) }\end{array}$ & 0.55 & 0.23 \\
\hline $\begin{array}{c}\text { Shear strength in the W } \\
\text { direction (MPa) }\end{array}$ & 1.73 & 0.65 \\
\hline $\begin{array}{c}\text { Shear modulus } \\
\text { in the W direction (GPa) }\end{array}$ & 0.23 & 0.12 \\
\hline
\end{tabular}

Table 3. Material properties of honeycomb cores

\section{EXPERIMENTAL MEASUREMENT}

The composite sandwich panel was made using a flat mould in two cycles with curing in an autoclave at an overpressure of 0.3 and $0.6 \mathrm{MPa}$ and a temperature of $120^{\circ} \mathrm{C}$. The individual layers were manually placed in a flat mould. An adhesive film IMP380FHC Black, 250 g. $\mathrm{m}^{-2}$ produced by Impregnatex Compositi company. was used to join the skins and the core. Twelve test specimens with two different cores and two different thickness of skin were made for experimental measurement of flexural stiffness. The specimen list is given in Tab. 1, which gives the panel thickness.

The specimens were labelled with the following system:

$P$ [no of skin layers]_C[size of cell honeycomb/density of core]_S[serial number of the specimen]

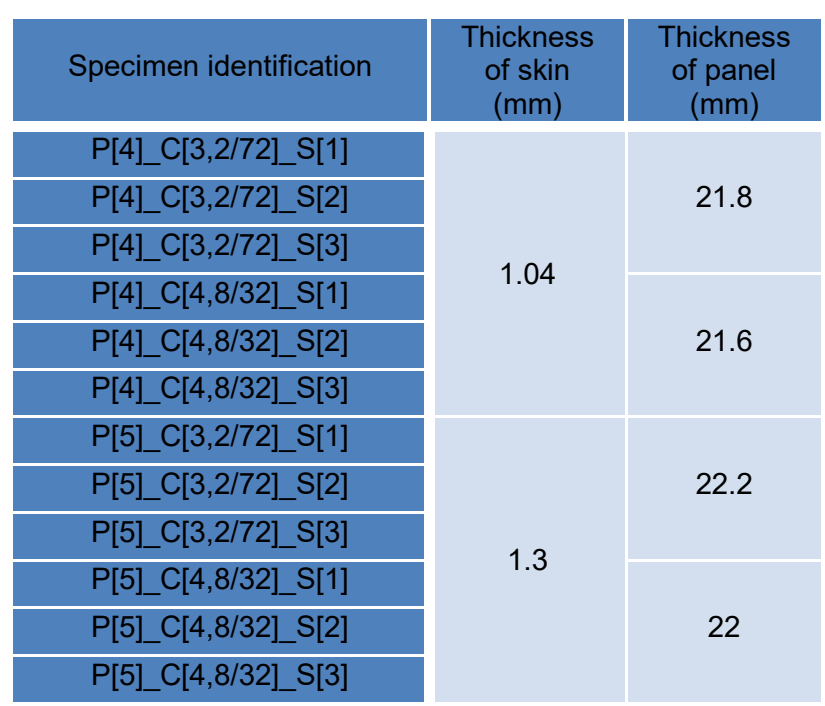

Table 4. Overview of test specimens for the determination of bend stiffness with thickness

Flexural stiffness tests were performed with a quasi-static load of $5 \mathrm{~mm}$.min-1 on a Zwick Roell Z050 tester. The three-point bend test was performed in accordance with ASTM C393 [ASTMC393 2020]. The test procedure was shown in the Fig. 4 The measuring deflection was performed by a measuring arm where it was in contact with the lower part of the load element. The measurement results are not affected by the deformation of the cross member but include the local deformation of the panel in contact with the load element.

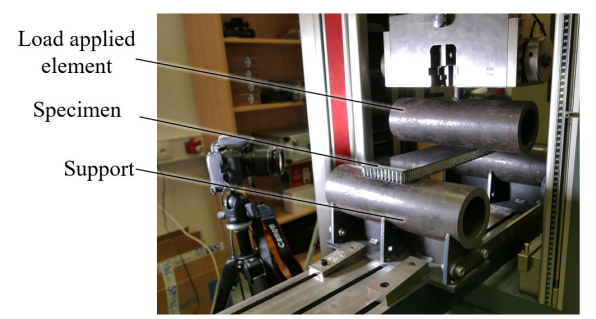

Figure 4. Alignment of test specimens on test stand

The measured values were shown in the Graph 1 and Tab. 5. The values were measured mainly with a deviation of up to $7.7 \%$. The deviation $12.1 \%$ of the maximum deflection from average for specimens $P[5]$ C $[4,8 / 32]$ was caused by lower measured value for the specimen P [5]_C [4,8/32] _[S1]. The deflection and the loading force in the linear deformation region of the specimens were determined for a more accurate comparison, see Tab. 6. To compare specimen, it was calculated the equivalent Young's modulus $E_{e k v}$. The modulus of elasticity in shear for the assessed samples is unknown, therefore, the equation (2) was simplified to equation (1) by neglect of the deflection caused by the shear load $\delta_{s}$. This made it possible to determine the equivalent Young's modulus $E_{e k v}$. The equivalent Young's modulus $E_{e k v}$ was calculated according to equation (1) and deflection and the loading force in the linear deformation region, see Tab. 6. According to the equivalent Young's modulus, the flexural stiffness was measured with a maximum deviation of $4.7 \%$.

$\delta=\frac{F L^{3}}{48 E_{e k v} I_{y}}$

where $\delta$ is panel deflection (m), $F$ is appled load, $L$ is distance of span (m); $E_{e k v}$ is Equivalent Young's modulus (Pa); $I_{y}$ is quadratic cross-sectional bending moment for a rectangular profile $\left(\mathrm{m}^{4}\right)$ 


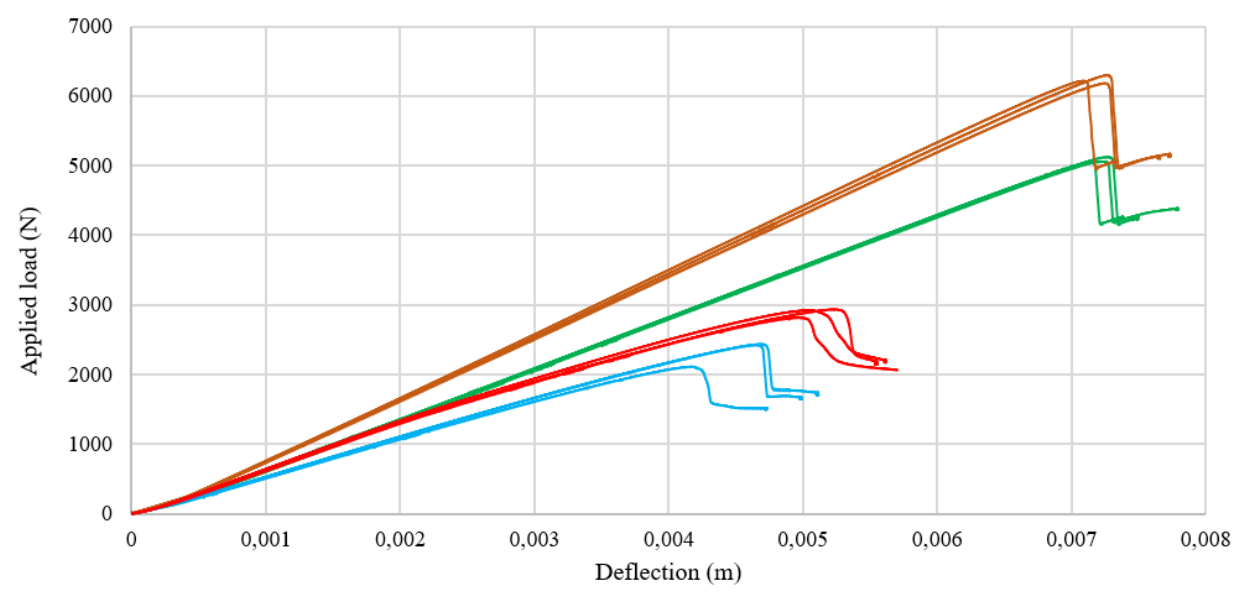

- Ohyb_P[4]_C[3,2/72]_S[1]

Ohyb_P[4]_C[3,2/72]_S[2]

- Ohyb_P[4]_C[3,2/72]_S[3]

- Ohyb_P[4]_C[4,8/32]_S[1]

- Ohyb_P[4]_C[4,8/32]_S[2]

- Ohyb_P[4]_C[4,8/32]_S[3]

- Ohyb_P[5]_C[3,2/72]_S[1]

- Ohyb_P[5]_C[3,2/72]_S[2]

- Ohyb_P[5]_C[3,2/72]_S[3]

- Ohyb_P[5]_C[4,8/32]_S[1]

- Ohyb_P[5]_C[4,8/32]_S[2]

- Ohyb_P[5]_C[4,8/32]_S[3]

\begin{tabular}{|c|c|c|c|c|c|c|}
\hline Specimen identification & $\begin{array}{l}\text { Maximum } \\
\text { load } \\
(\mathrm{N})\end{array}$ & $\begin{array}{l}\text { Maximum } \\
\text { deflection } \\
(\mathrm{mm})\end{array}$ & $\begin{array}{l}\text { Average } \\
\text { maximum } \\
\text { load } \\
(\mathrm{N})\end{array}$ & $\begin{array}{l}\text { Deviation } \\
\text { of max. } \\
\text { load from } \\
\text { average } \\
(\%)\end{array}$ & $\begin{array}{l}\text { Average } \\
\text { maximum } \\
\text { deflection } \\
(\mathrm{mm})\end{array}$ & $\begin{array}{c}\text { Deviation of } \\
\text { max. deflection } \\
\text { from average } \\
(\%)\end{array}$ \\
\hline$P[4] \_C[3,2 / 72] \_S[1]$ & 5117.9 & 7.28 & \multirow{3}{*}{5076.1} & \multirow{3}{*}{1.3} & \multirow{3}{*}{7.5} & \multirow{3}{*}{6.8} \\
\hline $\mathrm{P}[4] \_\mathrm{C}[3,2 / 72] \_\mathrm{S}[2]$ & 5056.6 & 7.79 & & & & \\
\hline$P[4] \_C[3,2 / 72] \_S[3]$ & 5053.8 & 7.38 & & & & \\
\hline $\mathrm{P}[4] \_\mathrm{C}[4,8 / 32] \_\mathrm{S}[1]$ & 2420.3 & 4.99 & \multirow{3}{*}{2320.8} & \multirow{3}{*}{13.9} & \multirow{3}{*}{4.9} & \multirow{3}{*}{7.7} \\
\hline $\mathrm{P}[4] \_\mathrm{C}[4,8 / 32] \_\mathrm{S}[2]$ & 2432.4 & 5.11 & & & & \\
\hline $\mathrm{P}[4] \_\mathrm{C}[4,8 / 32] \_\mathrm{S}[3]$ & 2109.8 & 4.73 & & & & \\
\hline $\mathrm{P}[5] \_\mathrm{C}[3,2 / 72] \_\mathrm{S}[1]$ & 6296.5 & 7.73 & \multirow{3}{*}{6231.0} & \multirow{3}{*}{1.9} & \multirow{3}{*}{7.6} & \multirow{3}{*}{5.4} \\
\hline$P[5] \_C[3,2 / 72] \_S[2]$ & 6215.6 & 7.32 & & & & \\
\hline$P[5] \_C[3,2 / 72] \_S[3]$ & 6180.9 & 7.65 & & & & \\
\hline $\mathrm{P}[5] \_\mathrm{C}[4,8 / 32] \_\mathrm{S}[1]$ & 2813.7 & 4.96 & \multirow{3}{*}{2887.6} & \multirow{3}{*}{4.1} & \multirow{3}{*}{5.4} & \multirow{3}{*}{12.1} \\
\hline $\mathrm{P}[5] \_\mathrm{C}[4,8 / 32] \_\mathrm{S}[2]$ & 2918,2 & 5,61 & & & & \\
\hline $\mathrm{P}[5] \_\mathrm{C}[4,8 / 32] \mathrm{S}[3]$ & 2931,0 & 5,55 & & & & \\
\hline
\end{tabular}

Table 5. Result of experimental measurements of 3-point bend test

\begin{tabular}{|c|c|c|c|c|c|}
\hline Specimen identification & $\begin{array}{l}\text { Loads in } \\
\text { the linear } \\
\text { area } \\
(\mathrm{N})\end{array}$ & $\begin{array}{l}\text { deflection } \\
\text { in the } \\
\text { linear area } \\
(\mathrm{mm})\end{array}$ & $\begin{array}{l}\text { Equivalent } \\
\text { Young's } \\
\text { modulus } \\
(\mathrm{GPa})\end{array}$ & $\begin{array}{l}\text { Average value of } \\
\text { equivalent } \\
\text { Young's modulus } \\
\text { (GPa) }\end{array}$ & $\begin{array}{l}\text { Deviation of } \\
\text { equivalent Young's } \\
\text { modulus from } \\
\text { average } \\
(\%)\end{array}$ \\
\hline $\mathrm{P}[4] \_\mathrm{C}[3,2 / 72] \_\mathrm{S}[1]$ & 4000 & 5.49 & 11.25 & \multirow{3}{*}{11.2} & \multirow{3}{*}{0.3} \\
\hline $\mathrm{P}[4] \_\mathrm{C}[3,2 / 72] \_\mathrm{S}[2]$ & 4000 & 5.51 & 11.22 & & \\
\hline $\mathrm{P}[4] \_\mathrm{C}[3,2 / 72] \_\mathrm{S}[3]$ & 4000 & 5.51 & 11.22 & & \\
\hline $\mathrm{P}[4] \_\mathrm{C}[4,8 / 32] \_\mathrm{S}[1]$ & 1500 & 2.67 & 8.91 & \multirow{3}{*}{8.8} & \multirow{3}{*}{4.7} \\
\hline $\mathrm{P}[4] \_\mathrm{C}[4,8 / 32] \_\mathrm{S}[2]$ & 1500 & 2.66 & 8.96 & & \\
\hline $\mathrm{P}[4] \_\mathrm{C}[4,8 / 32] \_\mathrm{S}[3]$ & 1500 & 2.79 & 8.55 & & \\
\hline$P[5] \_C[3,2 / 72] \_S[1]$ & 5000 & 5.54 & 13.19 & \multirow{3}{*}{13.2} & \multirow{3}{*}{2.6} \\
\hline $\mathrm{P}[5] \_\mathrm{C}[3,2 / 72] \_\mathrm{S}[2]$ & 5000 & 5.48 & 13.34 & & \\
\hline $\mathrm{P}[5] \_\mathrm{C}[3,2 / 72] \_\mathrm{S}[3]$ & 5000 & 5.62 & 13.00 & & \\
\hline $\mathrm{P}[5] \_\mathrm{C}[4,8 / 32] \_\mathrm{S}[1]$ & 2000 & 3.18 & 9.44 & \multirow{3}{*}{9.6} & \multirow{3}{*}{3.0} \\
\hline $\mathrm{P}[5] \_\mathrm{C}[4,8 / 32] \_\mathrm{S}[2]$ & 2000 & 3.09 & 9.73 & & \\
\hline $\mathrm{P}[5] \_\mathrm{C}[4,8 / 32] \mathrm{S}[3]$ & 2000 & 3.16 & 9.50 & & \\
\hline
\end{tabular}

Table 6. Result of o3-point bend experimental measurement in linear region of deflection 
In the case of the specimen with the core PAMG-XR1-2.0-3 / 1607-P-5056, which has many times less compressive strength than PAMG-XR1-4.5-1 / 8-10-P-5056, there was a local collapse of the core in contact with the load element, see Fig. 5, 6 .

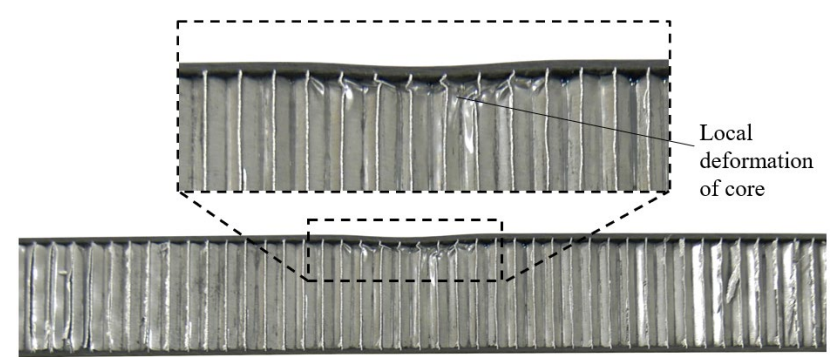

Figure 5. Side view of a local core failure under pressure for a specimen $\mathrm{P}[4]$ C $[3,2 / 72]$

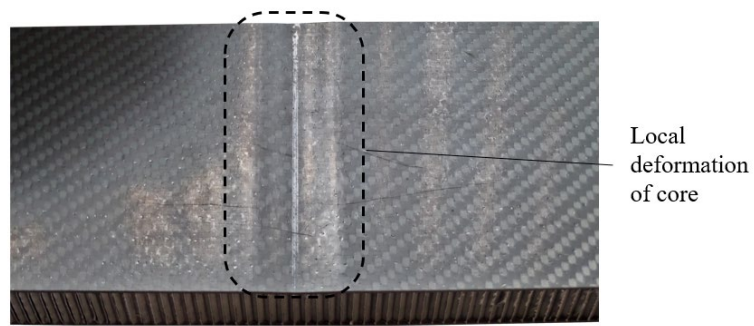

Figure 6. Top view of a local core failure under pressure for a specimen $\mathrm{P}[4]+C[3,2 / 72]$

\section{ANALYTICAL CALCULATION}

The following assumptions were established for the analytical calculation of the stiffness of the sandwich panel: [Barbero 2010]

- The orthotropic skin material was replaced by an isotropic material with one value of the tensile Young's modulus $E_{f}$.

- The orthotropic core material was replaced by an isotropic material with one value of the Young's modulus in compression $E_{c}$ and one value of the shear stiffness $G_{c}$.

- The Young's modulus of the skin is several times greater than the Young's modulus of the core; $E_{f} \ll E_{c}$.

- The thickness of the skin $t$ is several times smaller than the thickness of the core $\mathrm{c} ; t \ll c$

The sandwich composite beam with marked sizes of given dimensions is shown in Fig. 7.
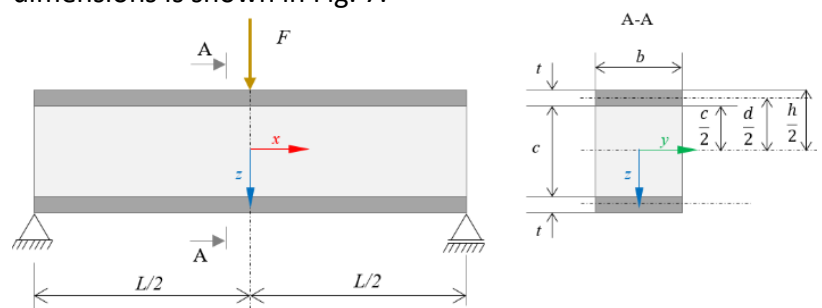

Figure 7. Sandwich composite beam in three - point bending position with a section in place

where $L / 2$ is half distance of span $(\mathrm{m}), F$ is appled load (N), $b$ is width of panel $(\mathrm{m}), t$ is thickness of skin $(\mathrm{m}), c$ is thickness of core (m), $d / 2$ is half of middle distance of skins $(\mathrm{m}), h / 2$ is half of thickness of panel $(\mathrm{m})$.
The sandwich beam loaded by a 3-point bend creates a compressive stress in the upper skin and a tensile stress in the lower skin. The core that connects the upper and lower skin is stressed by shear stress. This fact ensures that the sandwich panel behaves as a homogeneous structure. The stress distribution in the sandwich panel due to the given assumptions was shown in Fig. 8.

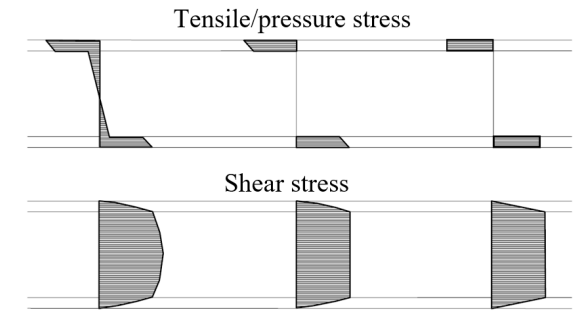

Without prerequisites $\quad E_{f} \ll E_{c} \quad E_{f} \ll E_{c} ; t \ll c$

Figure 8. Distribution of normal and shear stress of a sandwich beam in bending [Zenkert 1995]

where $E_{f}$ is Young's modulus in tension of skin $(\mathrm{Pa}), E_{c}$ is Young's modulus in compress of core (Pa), $t$ is thickness of skin $(\mathrm{m}), c$ is thickness of core $(\mathrm{m})$.

The total deflection of the panel in the bending $\delta$ is given by the sum of the deflection caused by the bending stress $\delta_{b}$ (Fig. 9 shown in green) a and the deflection caused by the shear load $\delta_{s}$ (Fig. 9 shown in red). The total deflection of the panel is given by Eq. 2. [Hexcel Composites 2019]

$$
\delta=\delta_{b}+\delta_{s}
$$

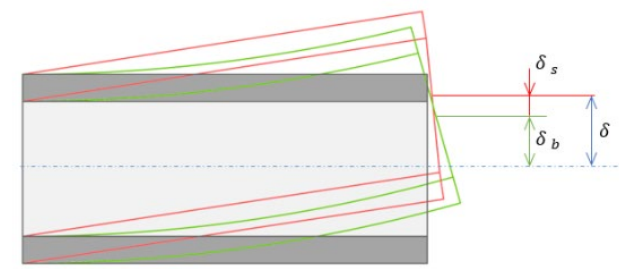

Figure 9. Sandwich panel deformation caused by bending and shear

$$
\delta=\frac{F L^{3}}{24 E_{f} b t d^{2}}+\frac{F L}{4 b d G_{c}}
$$

where $\delta$ is total deflection $(\mathrm{m}), F$ is appled load $(\mathrm{N}), L$ is distance of span (m); $E_{f}$ is modulus of elasticity in tension of skin (Pa); $b$ is width of panel $(\mathrm{m}), t$ is thickness of skin $(\mathrm{m}), d$ is middle distance of skins $(\mathrm{m}), G_{c}$ is modulus of elasticity in the shear of the core (pa).

The deflections of the selected panels were calculated by analytical calculation, according to Eq. 3 and the load values for the linear deformation in Tab. 6. The results are shown in Tab. 7.

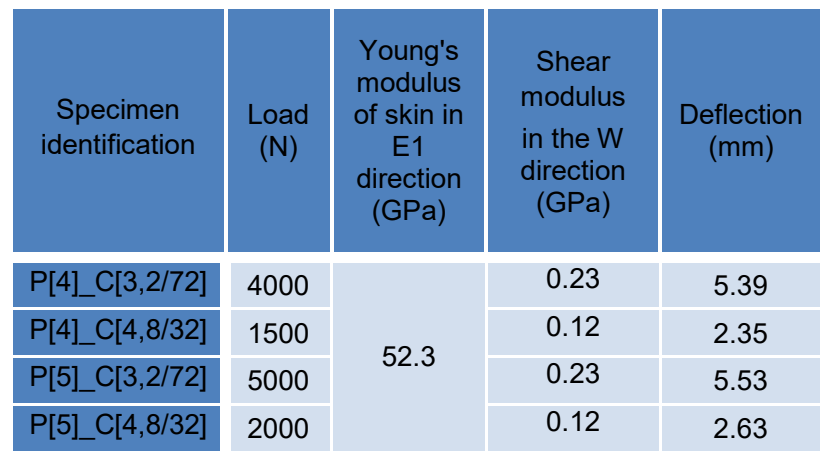

Table 7. Result of o3-point bend analytical calculation 


\section{NUMERICAL ANALYSIS}

Numerical simulations were performed in a structural linear solver NX Nastran (SOL101) and a pre-/postprocessor Siemens Simcenter 12 [Goncharov 2014].

The FEM models of a composite sandwich panel can be divided into two basic groups: the discrete modelling and the continuum model. In the discrete modelling approach, the honeycomb panel is modelled with the intricate cellular details of the core. Owing to the cell details and huge number of cells entailed in a full-scale honeycomb shell structure, this approach is rendered less preferable since it would require high computational time and is relatively difficult to create correctly. In continuum modelling approach, the cellular core of a honeycomb structure is replaced with an orthotropic layer of a continuum material. Such approach is far simpler in contrast to the former one as it involves only the shell elements spread over the span of the honeycomb. An accurate knowledge of the equivalent orthotropic core properties is a major concern in continuum modelling. Continuum properties can be found through experimentation or supplied by manufacturers of honeycomb cores [Rahman 2011]. For the above reasons, the continuum model was chosen. The equivalent orthotropic core properties were given by the manufacturer. The $2 \mathrm{D}$ mesh with eight nodes of the CQUAD8 type was applied to the 2D shell model. Subsequently, this mesh was extruded into 3D by special "extrude laminate" function. This FEM model is in this case represented by a individual layer of 3D elements (type CHEXA20) for each a ply or a core of the laminate/sandwich. The material properties of the core according to Tab. 3 and the material properties of the skin according to Tab. 2 were used for the FEM model.

Modelling of the adhesive join between the core and the honeycomb can be divided into two groups, with tied flexibility or neglected flexibility. Models that consider flexibility (include the core and the skin adhesive join failures) are, for example: 2D mesh of type "Thin shell", more advanced methods, which can also take into account failures and specific stiffness (in main directions) using cohesive elements or the XFEM method. Models that neglected flexibility are for example: model using only contact conditions of the gluing type (Tie), direct connection of mesh nodes (associated/merged nodes at the meshes of the plies interface). The sandwich beam was assessed from a macroscopic point of view and was manufactured under overpressure when the core comes into direct contact with the fabric, therefore the flexibility of the adhesive layer was neglected. The modelling methos of direct connection of mesh nodes was used in this case.

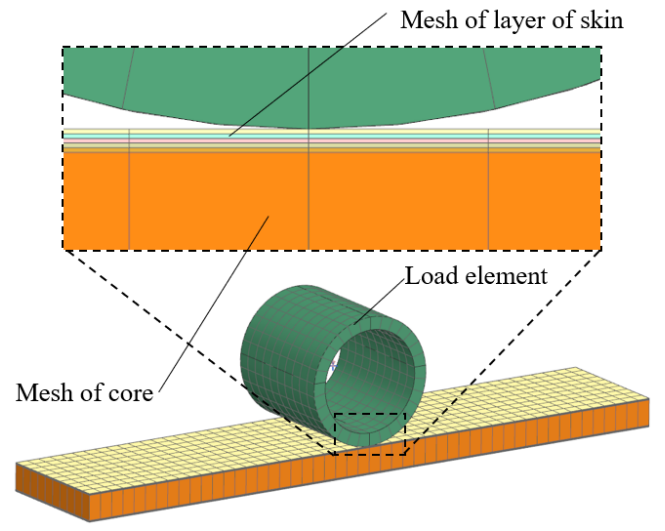

Figure 10. Mesh for numerical simulation of 3 -point bend test

The schema of a final mesh model with a rigid load element with a real shape and a dimension is given in Fig. 10. The three-point bending supports were replaced in the FEM model by the boundary condition of the forced displacement in the vertical direction. The results of the numerical simulations for all specimen are shown in Tab. 8. The results of the tensile and compressive stress for the top and bottom composite skins are given in Fig. 11, 12. The shear stress in the core is shown in Fig. 13. The individual specimen was loaded according to Tab. 6 (as in the case of the analytical calculation). All stress values of specimen P[5] _C $[4,8 / 32]$ (Fig. 11, 12, 13) were calculated for a loading force of $2000 \mathrm{~N}$.

\begin{tabular}{|c|c|c|c|c|}
\hline $\begin{array}{c}\text { Specimen } \\
\text { identification }\end{array}$ & $\begin{array}{c}\text { Load } \\
(\mathrm{N}) \\
\text { modulus } \\
\text { of skin } \\
\text { in E1 } \\
\text { direction } \\
(\mathrm{GPa})\end{array}$ & $\begin{array}{c}\text { Shear } \\
\text { modulus } \\
\text { in the W } \\
\text { direction } \\
(\mathrm{GPa})\end{array}$ & $\begin{array}{c}\text { Deflection } \\
(\mathrm{mm})\end{array}$ \\
\hline $\mathrm{P}[4][\mathrm{C}[3,2 / 72]$ & 4000 & & 0.23 & 5.37 \\
\hline $\mathrm{P}[4][C[4,8 / 32]$ & 1500 & 52.3 & 0.12 & 2.3 \\
\hline $\mathrm{P}[5][\mathrm{C}[3,2 / 72]$ & 5000 & & 0.23 & 5.49 \\
\hline $\mathrm{P}[5]+\mathrm{C}[4,8 / 32]$ & 2000 & & 0.12 & 2.57 \\
\hline
\end{tabular}

Table 8. Result of numerical simulation

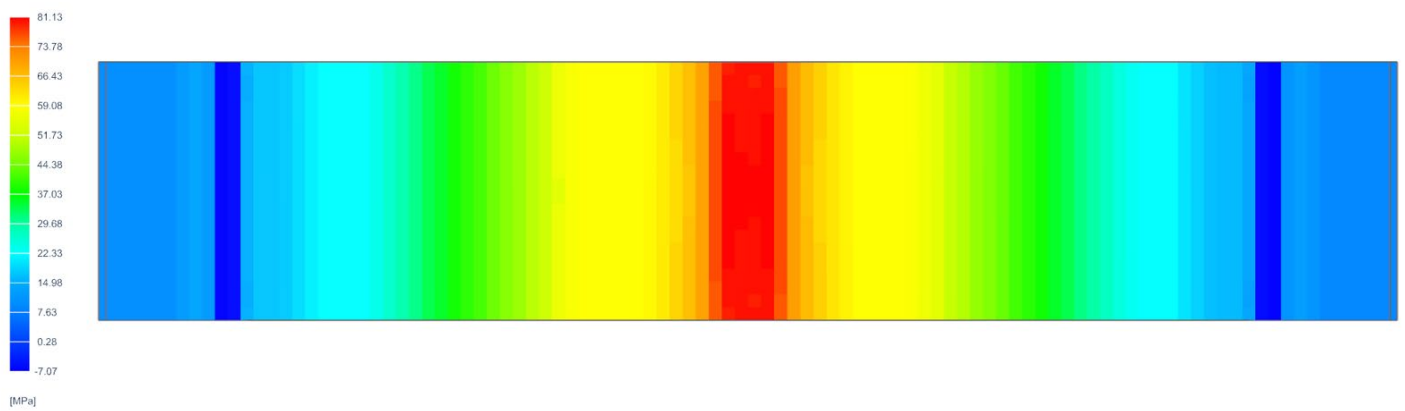

Figure 11. Tensile stress in the lower skin for the sample $\mathrm{P}[5]$ _ $C[4,8 / 32]$ 

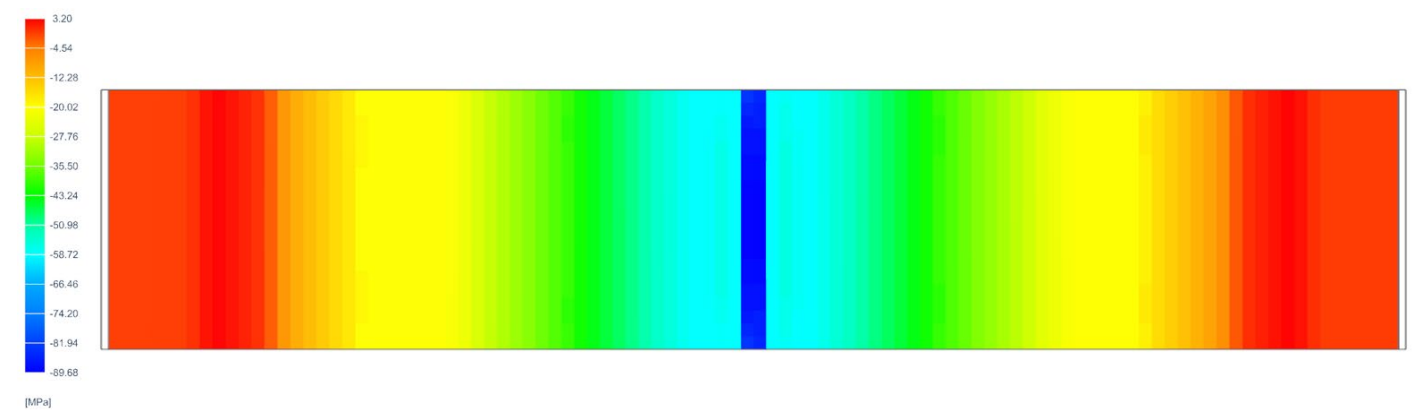

Figure 12. Compress stress in the upper skin for the sample $P[5] C[4,8 / 32]$

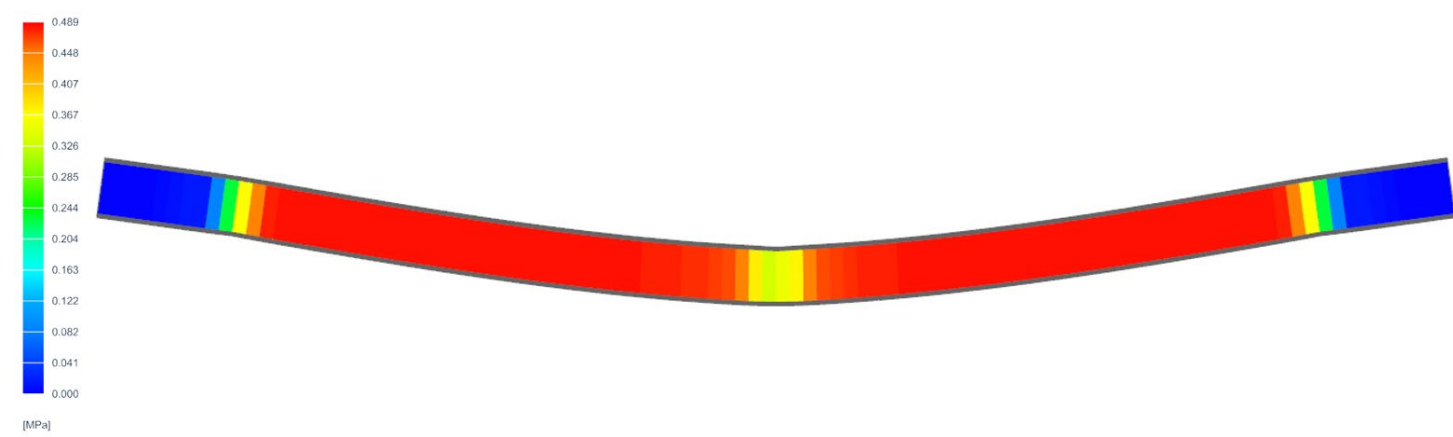

Figure 13. Shear stress in the core for the sample $\mathrm{P}[5] \mathrm{C}[4,8 / 32]$

\section{COMPARISON OF RESULTS}

The values of panel deflection from experimental measurements, numerical simulation and analytical calculation have been clearly stated in Tab. 9. The deviation of the experimentally measured values from the analytical calculation and numerical simulation for specimen with a core density of 72 $\mathrm{kg} \cdot \mathrm{m}^{-3}$ was up to $2.4 \%$. The same value of deviation for samples with a core density of $32 \mathrm{~kg} \cdot \mathrm{m}^{-3}$ was up to $18.3 \%$. This large deviation was caused by local plastic deformation of the core in shear. The result from numerical simulation and analytical calculation does not take this local deformation of the core does not include.

\begin{tabular}{|c|c|c|c|c|c|c|c|}
\hline \multirow[b]{2}{*}{$\begin{array}{l}\text { Specimen } \\
\text { identification }\end{array}$} & \multirow[b]{2}{*}{$\begin{array}{l}\text { Load } \\
(\mathrm{N})\end{array}$} & \multirow{2}{*}{$\begin{array}{c}\begin{array}{c}\text { Experimental } \\
\text { measurement }\end{array} \\
\begin{array}{c}\text { Deflection } \\
(\mathrm{mm})\end{array}\end{array}$} & \multicolumn{2}{|c|}{ Analytical calculation } & \multicolumn{2}{|c|}{ Numerical analysis } & \multirow{2}{*}{$\begin{array}{l}\text { Deviation } \\
\text { analytical } \\
\text { calculation } \\
\text { from } \\
\text { numerical } \\
\text { analysis } \\
(\%)\end{array}$} \\
\hline & & & $\begin{array}{l}\text { Deflection } \\
(\mathrm{mm})\end{array}$ & $\begin{array}{l}\text { Deviation } \\
\text { from exp. } \\
\text { measurement } \\
\text { (\%) }\end{array}$ & $\begin{array}{l}\text { Deflection } \\
(\mathrm{mm})\end{array}$ & $\begin{array}{c}\text { Deviation } \\
\text { from exp. } \\
\text { measurement } \\
(\%)\end{array}$ & \\
\hline $\mathrm{P}[4] \_\mathrm{C}[3,2 / 72]$ & 4000 & 5.50 & 5.39 & 2.0 & 5.37 & 2.4 & 0.4 \\
\hline $\mathrm{P}[4] \_\mathrm{C}[4,8 / 32]$ & 1500 & 2.71 & 2.35 & 13.1 & 2.3 & 15.0 & 2.1 \\
\hline$P[5] \_C[3,2 / 72]$ & 5000 & 5.55 & 5.53 & 0.4 & 5.49 & 1.1 & 0.7 \\
\hline $\mathrm{P}[5] \_\mathrm{C}[4,8 / 32]$ & 2000 & 3.15 & 2.63 & 16.4 & 2.57 & 18.3 & 2.3 \\
\hline
\end{tabular}

Table 9. Comparison of result of from experimental measurements, numerical simulation and analytical calculation

\section{CONCLUSION}

The goal of this paper was to comparison numerical simulation and analytic calculation with experimental measurement of composite sandwich panel with aluminium honeycomb core. The deflection result deviation of the analytical calculation from the numerical simulation was very small. For samples $\mathrm{P}[4]$ C $[3,2 / 72]$ and $\mathrm{P}[5] \_\mathrm{C}[3,2 / 72]$ with a stiffer core, a deflection deviation of up to $1 \%$ was calculated and for samples $\mathrm{P}[4][\mathrm{C}[4,8 / 32]$ and $\mathrm{P}[5] \mathrm{C}[4,8 / 32]$ a deviation of up to $2.3 \%$ was calculated. The deflection result deviation of the analytical calculation and numerical simulation from the experimental measurements reached the value of $18.3 \%$. The measuring deflection of experimental measurement was performed by a measuring arm where it was in contact with the lower part of the load element. The measurement results are not affected by the deformation of the cross member but include the local deformation of the panel in contact with the load element. For samples $\mathrm{P}[4]$ _C $[3,2 / 72]$ and $\mathrm{P}[5]$ _C $[3,2 / 72]$ with a stiffer core, the deflection deviation from the experimental measurement was calculated from 0.4 to $2.4 \%$. For samples $\mathrm{P}[4]$ [C [4,8/32] and $\mathrm{P}[5]$ C $[4,8 / 3]$, a deviation from 13.1 to $18.3 \%$ was calculated. This large deviation up to $18.3 \%$ for specimen with a core with lower stiffness was caused by local deformation of the core in contact area with the load element. The result from numerical simulation and analytical calculation does not take this local deformation of the core does not include. However, the local deformation of the core in contact with the load element can be predicted by analytical calculation or numerical simulation. This can prevent errors in the given comparison with the experimental measurement. This can prevent errors in the given comparison with the experimental measurement. The FEM model for numerical simulation used the continuum model of core and direct connection of mesh nodes for adhesive joint modelling. This paper confirms the possibility of a very precise design of a composite sandwich panel with an aluminium honeycomb core using analytical calculation and numerical simulation with an accuracy of up to $2.4 \%$ if the local 
deformation of the core in contact area with the load element does not occur.

\section{ACKNOWLEDGMENTS}

This article was prepared under the project SGS-2019-030 Research and Development of Advanced Components for a Formula Student Car.

\section{REFERENCES}

[ASTM-C393 2020] ASTM International. Standard Test Method for Core Shear Properties of Sandwich Constructions by Beam Flexure C393/C393M - 06.USA: ASTM International 2020.

[Barbero 2010] E.J Barbero. Introduction to Composite Materials Desig. USA: Taylor \& Francis Inc, Boca Raton. ISBN 978-1-43989413-2

[Bitzer 1997] T. Bitzer. Honeycomb Technology: Materials, Design, Manufacturing, Applications and Testing. Netherlands: Springer-Science+Business media, B.V., 1997. ISBN 978-0-41254050-9

[Campbell 2010] F. C. Campbell, Structural Composite Materials. USA : ASM International, 2010. ISBN 978-1-6150-3140-5

[Goncharov 2014] P. Goncharovl., Artamonov T., Khalitov. Engineering Analysis With NX Advanced Simulation. USA: Lulu Publishing Services, 2014. ISBN 9781483417325

[Hexcel Composites 2019] HexWebTM Honeycomb Sandwich Design Technology 2019. 27.9.2021 https://www.hexcel.com /Resources/Technology

[Skovajsa 2021] M. Skovajsa, R. Kroft, F. Sedlacek. Numerical and experimental modal analysis of a carbon fibre monocoque. MM Science Journal, 2021, DOI:10.17973/MMSJ.2021_6_2021 048

[Rahman 2011] H. Rahman, R. Jamshed, H. Hameed, S. Raza. Finite Element Analysis (FEA) of Honeycomb Sandwich Panel for Continuum Properties Evaluation and Core Height Influence on the Dynamic Behavior. Switzerland: Trans Tech Publications, 2011. doi:10.1016/S0045-7825(96)01196-6

[Zenkert 1995] D. Zenkret. Introduction to Sandwich Construction. UK: Warley, West Midlands:. ISBN 978-0-94781777-0

\section{CONTACTS:}

Ing. Michal Skovajsa, Ph.D.

University of West Bohemia, Faculty of Mechanical Engineering Univerzitni 8, Plzen, 30100, Czech Republic

+420 377631 111, skovi@kks.zcu.cz,www.zcu.cz 